\title{
Breakdown of Cross-Protection of Grapefruit from Decline-Inducing Isolates of Citrus tristeza virus Following Introduction of the Brown Citrus Aphid
}

\author{
C. A. Powell, R. R. Pelosi, P. A. Rundell, and M. Cohen, University of Florida, IFAS, Indian River Research and \\ Education Center, Fort Pierce 34945
}

\begin{abstract}
Powell, C. A., Pelosi, R. R., Rundell, P. A., and Cohen, M. 2003. Breakdown of cross-protection of grapefruit from decline-inducing isolates of Citrus tristeza virus following introduction of the brown citrus aphid. Plant Dis. 87:1116-1118.

A 21-year-old replicated field planting of 84 'Ruby Red' grapefruit trees cross-protected with three mild isolates of Citrus tristeza virus (CTV) was assessed for decline-inducing and nondecline-inducing isolates of the virus 5 years after the brown citrus aphid (BrCA) (Toxoptera citricida Kirkaldy) first was established in the experimental area. Prior to the introduction of the $\mathrm{BrCA}$, the cross-protecting mild isolates had significantly reduced detectable infection with decline-inducing isolates of CTV for 16 years (average infection of $13 \%$ in cross-protected trees compared with $67 \%$ in unprotected trees). After the introduction of the BrCA, infections with decline-inducing CTV (measured by enzyme-linked immunosorbent assay) were 57, 81, and $71 \%$ for trees protected with three mild isolates, respectively, compared with $95 \%$ in unprotected trees. These results suggest that the introduction of BrCA accelerated the breakdown of cross-protection against decline-inducing isolates of CTV in grapefruit.
\end{abstract}

Citrus tristeza virus (CTV) causes economically important diseases of citrus worldwide $(1,3)$. The virus can cause a variety of symptoms, including stunting, slow decline, quick decline, stem-pitting, or undersized fruit, or infected trees may be symptomless (2). The symptomology is influenced by many factors, including virus isolate, citrus scion cultivar, rootstock, time of infection, and environmental conditions. In Florida, CTV isolates that do not cause symptoms and those that cause stunting, slow decline, or quick decline of citrus on sour orange (Citrus aurantium L.) or related rootstock are common, but those isolates that cause stem-pitting regardless of the rootstock are not common in commercial citrus.

Control of CTV-induced diseases in Florida has focused on replacing sour orange with rootstock that is unaffected by endemic CTV isolates, a budwood certification program to prevent introduction of stem-pitting or decline-inducing isolates of CTV into productive groves, and crossprotection of existing groves on sour orange rootstock from decline-inducing CTV. The alternate rootstock strategy has been effective throughout most of Florida, but

Corresponding author: C. A. Powell

E-mail: CAPowell@mail.ifas.ufl.edu

Florida Agriculture Experiment Station Journal Series R-08883.

Accepted for publication 22 April 2003.

Publication no. D-2003-0627-01R

(C) 2003 The American Phytopathological Society some Florida soils are best suited for sour orange rootstock and substitute rootstocks do not perform as well horticulturally. Budwood certification has been successful in reducing the chance of replants introducing disease-inducing CTV into healthy groves (C. A. Powell, unpublished data).

Cross-protection has had both successes $(4,9,11)$ and failures (8) in Florida. A sweet orange $(C$. sinensis $(\mathrm{L}$.) Osbeck) planting on sour orange rootstock protected with three mild isolates of CTV was in decline after 8 years (8). However, adjacent 'Ruby Red' grapefruit ( $C$. paradisi Macfad.) trees on sour orange rootstock protected with the same mild isolates had significantly less detectable infection with decline-inducing isolates of CTV than unprotected controls after 16 years (9). Both these experiments were analyzed (1989 for the sweet orange and 1977 for the grapefruit) prior to the introduction of the brown citrus aphid (BrCA) (Toxoptera citricida Kirkaldy) into the experimental area.

In 1997, the BrCA became prevalent in the Indian River region of Florida. This was a concern because of the reported increased efficiency of transmission of CTV by the BrCA (10). During that spring and summer, almost every new flush in the cross-protected grapefruit block was heavily infested with the aphid. In subsequent years, the BrCA has made sporadic but not sustained appearances. The grapefruit block in which trees are cross-protected by one of three mild isolates of CTV or unprotected was reevaluated for infection with decline-inducing isolates of CTV and tree health. The objective was to determine if cross-protection of the grapefruit would withstand the CTV transmission by the supposedly more efficient vector.

\section{MATERIALS AND METHODS}

Field plot design. The field plot that was assayed for CTV and rated for decline and tree health, located at the Indian River Research and Education Center, Fort Pierce, FL, was the same as that described in a previous report (9). Within each block, 3 trees that were propagated from CTVfree (by grafting indictors) material were inoculated with each of the isolates (DD $102 \mathrm{bb}$, Guettler HS, and DPI 1-12-5-X-E) of CTV; 3 trees were mock-inoculated with CTV-free buds; and all 12 trees were randomized within each of seven blocks. Each plot contained 12 trees on two single-row raised beds, with 6 trees on one bed and 6 on the adjacent bed. The seven plots were planted adjacent to each other in an eastwest direction at the Indian River Research and Education Center at Ft. Pierce in 1981. The experimental area, therefore, consisted of two rows with 42 trees per row. The experimental area was adjacent to the plots that were used to evaluate these same CTV isolates for cross-protection of sweet orange on sour orange rootstock (8). The Ruby Red grapefruit blocks were irrigated as needed with a microsprinkler system. Pathogens and pests were controlled as needed by application of pesticides according to University of Florida recommendations. No insecticides were applied to specifically control aphids.

Virus isolates and tree propagation. The three mild isolates of CTV (DD 102 bb, Guettler HS, and DPI 1-12-5-X-E) were described in earlier reports on crossprotection of 'Valencia' sweet orange (8) and Ruby Red grapefruit (9) on sour orange rootstock. Each of these isolates originated from a surviving sweet orange tree on sour orange rootstock where most of the nearby trees were in decline. Inoculation of 'Mexican' lime (Citrus aurantifolia) (L.) Swingle), with buds from the declining but not the surviving trees, induced vein clearing, stunting, and stem pitting in the indicator. Each of the three isolates initially was transferred by grafting from the field tree into several CTVfree Valencia sweet orange trees on sour orange rootstock using three scion bark chips per tree. These inoculum source trees were maintained in an aphid-free greenhouse. The presence of CTV in these trees was confirmed by enzyme-linked immu- 
nosorbent assay (ELISA), and the mild phenotype of each of the transferred isolates was verified by indexing on Mexican lime and sweet orange on sour orange indicators.

Budwood from the greenhouse trees containing each of the three mild isolates of CTV was used to inoculate CTV-free Ruby Red grapefruit on sour orange rootstock. As a control, grapefruit also were mock inoculated using buds from a virusfree Valencia sweet orange tree. The presence or absence of CTV in the grapefruit was verified by ELISA prior to transplanting the trees into the field.

Data collection. In the spring of 2001, 21 years after the blocks were planted, trees were evaluated for virus content, decline symptoms, and general health. Virus content was evaluated by indirect double-antibody sandwich (DAS)-ELISA (6) and in situ immunoassay (ISIA) (6) using monoclonal antibodies that react either with only severe CTV isolates (MCA13) (7) or with all Florida CTV isolates (17G11). The details of the DASELISA procedure (6) and ISIA (6) were described previously. Each sample consisted of a composite of young flush from three different locations on the tree. Samples were processed with a Kleco pulverizer (Kinetic Laboratory Equipment Company, Visailia, CA), as previously described (8). Criteria for judging whether a tree was positive were as previously described (6).

Trees were evaluated for decline in the spring of 2002. A tree was rated as in decline if its foliage was visually thinner than that of healthy trees. Tree ratings were taken at the same time using a 0 -to-3 scale, with 0 being no symptoms, 1 being slight decline, 2 being moderate decline, and 3 being severe decline (near death) (9). Thus, trees were first rated on a plus-or-minus scale for CTV-like symptoms, then rated on the severity of these symptoms.

Statistical analyses. Percent infection, percent decline, tree rating, and tree height data were subjected to an analyses of variance (ANOVA) by the SAS software program (SAS Institute, Cary, NC). Main treatment effect means that had a significant $F$ test were separated by Duncan's multiple range test, $5 \%$ level.

\section{RESULTS AND DISCUSSION}

The incidence of decline-inducing isolates of CTV and the condition of the grapefruit trees protected with non-declineinducing CTV is compared after 16 years (9) (prior to BrCA infestation) and 21 years (after BrCA infestation) (Table 1). After 21 years in the field, all the control grapefruit trees, which were not infected with CTV when planted, were now infected with the virus. After 16 years, $67 \%$ of the control trees were infected with decline-inducing CTV compared with $95 \%$ after 21 years. After 16 years, 14, 10, and $14 \%$ of the trees originally inoculated with the DD 102 bb, Guettler HS, and DPI 112-5-X-E mild isolates of CTV, respectively, were infected with decline-inducing CTV. This increased to 57,81 , and $71 \%$, respectively, for trees protected by these isolates after an additional 5 years. After 21 years in the field and 5 years of infestation with BrCA, DD 102 bb continued to provide protection against detectable infection with decline-inducing isolates of CTV.

In contrast to the 16-year data, most of the grapefruit trees in the block were in decline after 21 years. Decline and tree ratings also increased considerably after 5 years of BrCA infestation. Some trees were in decline and had a poor tree rating which were not infected with detectable CTV. These trees had suffered considerable root damage from citrus root weevil (Diaprepes abbreviatus) larval feeding.

All of the trees that tested positive for CTV by ELISA also were positive by ISIA. However, four trees that assayed negative for decline-inducing CTV by ELISA were positive by ISIA. This confirms that ISIA can detect CTV in trees that test negative for the virus by ELISA (5). ISIA was not available when the 16year analyses were conducted.

The results suggest that the arrival of the BrCA hastened the breakdown of crossprotection in grapefruit. Prior to the BrCA, 8 of 63 cross-protected trees contained decline-inducing CTV detectable by ELISA after 16 years in the field. After an additional 5 years, during which the BrCA was present, an additional 36 cross-protected trees became infected with ELISAdetectable concentrations of decline-inducing CTV. However, it is possible that the post-BrCA increase in infection was coincidental, and was caused by higher inoculum levels or other unknown factors that affected aphid movement or transmission efficiency.

Cross-protection still may have value for grapefruit on sour orange rootstock using a non-decline-inducing isolate such as DD $102 \mathrm{bb}$. Even after 5 years of infestation with $\mathrm{BCA}$, at least one-third of the trees protected by this isolate did not contain detectable levels of decline-inducing CTV. The combined strategies of mild strain cross-protection and replanting with nursery stock certified as free from detectable decline-inducing CTV may allow several more years of productivity from the many remaining grapefruit on sour orange rootstock groves in Florida. The results do not suggest planting grapefruit on sour orange rootstock (even if cross-protected) where decline-inducing CTV is prevalent is a good management strategy.

\section{LITERATURE CITED}

1. Bar-Joseph, M., Roistacher, C. N., Garnsey, S. M., and Gumpf, D. J. 1981. A review on tristeza, an ongoing threat to citriculture. Proc. Int. Soc. Citric. 1:419-422.

2. Garnsey, S. M., Gumpf, D. J., Roistacher, C. N., Civerolo, E. L., Lee, R. F., Yokomi, R. K., and Bar-Joseph, M. 1987. Toward a standardized evaluation of the biological properties of citrus tristeza virus. Phytophylactica 19:151157.

3. Garnsey, S. M., and Lee, R. F. 1988. Tristeza. Pages 48-50 in: Compendium of Citrus Dis-

Table 1. Incidence of decline-inducing isolates of Citrus tristeza virus (CTV) and condition of grapefruit trees protected with mild virus isolates after 16 and 21 years $^{\mathrm{t}}$

\begin{tabular}{|c|c|c|c|c|c|c|c|c|c|}
\hline \multirow[b]{2}{*}{$\begin{array}{l}\text { Protecting } \\
\text { isolate }^{\mathrm{u}}\end{array}$} & \multicolumn{4}{|c|}{16 years } & \multicolumn{5}{|c|}{21 years } \\
\hline & $\begin{array}{c}\text { Infection } \\
(\%)^{\mathrm{v}}\end{array}$ & $\begin{array}{l}\text { Severe (\%, } \\
\text { ELISA) }\end{array}$ & $\begin{array}{c}\text { Decline } \\
(\%)^{x}\end{array}$ & $\begin{array}{c}\text { Tree } \\
\text { ratingy }\end{array}$ & $\begin{array}{c}\text { Infection } \\
(\%)^{\mathrm{v}}\end{array}$ & $\begin{array}{l}\text { Severe }(\%, \\
\text { ELISA) }^{w}\end{array}$ & $\begin{array}{l}\text { Severe }(\%, \\
\text { ISIA) })^{z}\end{array}$ & $\begin{array}{c}\text { Decline } \\
(\%)^{x}\end{array}$ & $\begin{array}{c}\text { Tree } \\
\text { ratingy }\end{array}$ \\
\hline DD 102 bb & 100 & $14 \mathrm{a}$ & $19 \mathrm{a}$ & 0.7 & 100 & $57 \mathrm{a}$ & $62 \mathrm{a}$ & 63 & 2.1 \\
\hline Guettler HS & 100 & $10 \mathrm{a}$ & $29 \mathrm{ab}$ & 0.9 & 100 & $81 \mathrm{~b}$ & $86 \mathrm{~b}$ & 75 & 2.0 \\
\hline DPI 1-12-5-X-E & 100 & $14 \mathrm{a}$ & $33 \mathrm{ab}$ & 0.9 & 100 & $71 \mathrm{~b}$ & $81 \mathrm{~b}$ & 69 & 2.1 \\
\hline None & 90 & $67 \mathrm{~b}$ & $43 \mathrm{~b}$ & 1.1 & 100 & $95 \mathrm{~b}$ & $95 \mathrm{~b}$ & 75 & 2.1 \\
\hline
\end{tabular}

${ }^{t}$ Data are the average of measurements from 21 trees in seven randomized complete blocks ( 3 trees of each treatment per block). Mean separation within a column by Duncan's multiple range test, 5\% level; 16-year data has been published previously (8).

u Protecting isolate. Trees were propagated on sour orange rootstock using buds from 'Ruby Red' grapefruit that had been infected previously with each mild isolate of CTV by graft inoculation. Control trees were mock inoculated with buds from uninfected trees.

${ }^{v}$ CTV infection: percentage of trees positive for CTV using monoclonal antibody 17G11, which reacts to most Florida CTV isolates, as measured by enzyme-linked immunosorbent assay (ELISA) or in situ immunoassay (ISIA).

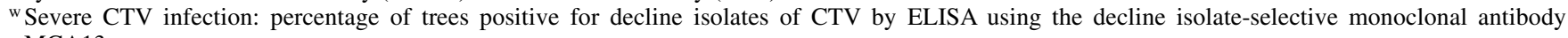
MCA13.

${ }^{x}$ Percentage of trees with moderate to severe decline (foliage visibly thinner than healthy trees).

y Rating on a scale of 0 to 3 , with $0=$ no symptoms, $1=$ slight decline, $2=$ moderate decline, and $3=$ severe decline (near death).

${ }^{\mathrm{z}}$ Severe CTV infection: percentage of trees positive for decline isolates of CTV by ISIA using the decline isolate-selective monoclonal antibody MCA13. 
eases. J. O. Whiteside, S. M. Garnsey, and L. W. Timmer, eds. American Phytopathological Society, St. Paul, MN.

4. Lee, R. F., and Brlansky, R. H. 1990. Evaluation of the use of mild strains of citrus tristeza virus to maintain mature citrus trees on sour orange rootstocks. Proc. Fla. State Hortic. Soc. 103:82.

5. Lin, Y., Rundell, P. A., and Powell, C. A. 2002. In situ immunoassay (ISIA) of field grapefruit trees inoculated with mild isolates of citrus tristeza virus indicated mixed infection with severe isolates. Plant Dis. 86:458-461.

6. Lin, Y., Rundell, P. A., Xie, L., and Powell, C. A. 2000. In situ immunoassay for detection of citrus tristeza virus. Plant Dis. 84:937-940.

7. Permar, T. A., Garnsey, S. M., Gumpf, D. J., and Lee, R. F. 1990. A monoclonal antibody that discriminates strains of citrus tristeza virus. Phytopathology 80:224-228.

8. Powell, C. A., Pelosi, R. R., and Cohen, M. 1992. Superinfection of orange trees containing mild isolates of citrus tristeza virus with severe Florida isolates of citrus tristeza virus. Plant Dis. 76:141-144.

9. Powell, C. A., Pelosi, R. R., Rundell, P. A., Stover, E., and Cohen, M. 1999. Cross-protection of grapefruit from decline-inducing isolates of citrus tristeza virus. Plant Dis. 83:989-991.
10. Yokomi, R. K., Garnsey, S. M., Permar, T. A Lee, R. F., and Youtsey, C. O. 1991. Natural spread of severe citrus tristeza virus isolates in citrus preinfected with mild CTV isolates. Pages 86-92 in: Proc. 11th Conf. Int. Organ. Citrus Virol., Riverside, CA.

11. Yokomi, R. K., Lastra, R., Stoetzel, M. B., Damsteegt, V. D., Lee, R. F., Garnsey, S M., Gottwald, T. R., Rocha-Pena, M. A. and Niblett, C. L. 1994. Establishment of the brown citrus aphid (Homoptera: Aphididae) in Central America and the Caribbean basin and transmission of citrus tristeza virus. J. Econ. Entomol. 87:10781085. 